\title{
Service of Transportation and Logistics at TPKS Semarang to Shorten the Dwelling Time in AEC Era
}

\author{
Sarjiyanto \\ Khoirul Muslimin \\ Fakultas Ekonomi dan Bisnis, Universitas Sebelas Maret \\ E-mail: masyanto@staff.uns.ac.id
}

\begin{abstract}
The purpose of this research is to describe the process of dwelling time itself, to identify related parties in the case, and the preparation strategies of Semarang Container Port (TPKS) facing the AEC. The research method used is descriptive, using qualitative and quantitative data. Data collection techniques are interviews with relevant parties, observations, and literature study. The results concluded the process of handling containers in Semarang TPKS potentially huge and causing dwelling time laid in pre-clearance process, customs clearance, and post-clearance process. Parties related to the dwelling time in Semarang Container Port (TPKS) are Custom (DJBC), Importers, and freight forwarding (PPJK). Preparation of Semarang Container Port in facing AEC in order to change the dwelling time by changing a manual system to an online system for clearance process, adding facilities, and improving human resources. The research findings indicate dwelling time length in Semarang Container Port (TPKS) reached 5.6 days which is still far from the government's target of 4.7 days Semarang Container Port (TPKS) has to simplify the system of the pre-clearance process, customs clearance, and post clearance. It needs to be done in order to reduce the length of dwelling time. Optimizations of performance also need to be improved with the Standard Operating Procedure. They also have to immediately perform optimization The Integrated Physical Checking Clearance which operates for 24 hours in one week.
\end{abstract}

Keywords: dwelling time, logistics export-import, ASEAN Economic Community

\begin{abstract}
ABSTRAK
Tujuan dari penelitian ini adalah untuk menggambarkan dwelling time, mengidentifikasi pihak terkait, dan strategi TPKS Semarang dalam menghadapi MEA. Metode yang digunakan adalah pendekatan deskriptif, dengan menggunakan data kualitatif dan kuantitatif. Teknik pengumpulan data adalah wawancara dengan pihak terkait, observasi, dan studi literatur. Hasil menyimpulkan proses handling di Semarang TPKS berpotensi besar dan menyebabkan dwelling time. Pihak yang terkait dwelling time di TPKS Semarang adalah Kepabeanan (DJBC), Importir, dan Freight Forwarding (PPJK). Persiapan TPKS Semarang dalam menghadapi MEA dengan mengubah proses clearance dari sistem manual ke sistem online untuk, menambah fasilitas peyalanan handling, dan meningkatkan sumber daya manusia. Temuan penelitian menunjukkan dwelling time di TPKS Semarang mencapai 5,6 hari yang masih jauh dari target pemerintah 4,7 hari Optimasi kinerja juga perlu ditingkatkan dengan membuat Standard Operating Procedure yang detail dan segera mendorong untuk melakukan percepatan pengurusan dokumen terkait, dan percepatan pelaksanaan pemeriksaan fisik, mulai memberlakukan TPFT secara 24 jam.
\end{abstract}

Keywords: Dwelling Time, Transportasi Ekspor-Impor dan Masyarakat Ekonomi ASEAN 


\section{Sarjiyanto \\ Khoirul Muslimin}

\section{INTRODUCTION}

Geographically, Indonesia is located between two oceans (India and Pacific Ocean) and two continents (Asia and Australia).Thus, Indonesia has an important position in global economic transportation. According to Rompas at all (2015), Indonesia is recognized country which lay across of the commercial shipping line. Sea transportation is considered as an easy and cheap transportation lines since the user do not have to invest in order to build transport line (such as road). Sea and ports as the gateway of traffic transport between countries, is the most important part to support international trade and commerce.

Port management system covers every aspect that related to activities in a harbor and other activities that is related to the execution harbor's function. It is actually in order to support celerity and safety of ship traffic, passenger, and goods (Suyono, 2005: 68).Tanjung Emas Container Port (TPKS), in Semarang is one of 10 biggest Harbors in Indonesia. Its function covers transportation service and logistic in international trade.

The management formof TPKS has beenchanged several times, started from harbor State's Corporation (Perusahaan Negara - PN) in 1960, Harbor Entrepreneur Agency (Badan Pengusahaan Pelabuhan-BPP) in 1969, and Harbor Public Company in 1983.TPKSis under Indonesia's Harbor Public Company III in Surabaya. The last form changed in 1992 but with the same allocation that are PT. (persero) Pelabuhan Indonesia (Indonesia Port Corporation - IPC) I, II, III, andIV.

In the beginning,container loading-unloading activities in Tanjung Emas Harbor were conducted conventionally. The process of loading-unloading activities is conducted under general cargo.It is managed bythe business division of Tanjung Emas Port's Terminal branch. After the second phase development in 1997, cargo handling is conducted separately under Cargo Terminal Division branch of Tanjung Emas Harbor(TPKS division).

As a preventive step on the increase in cargo's traffic at TPKSthe management of IPC III conducts Port's areaexpansion. This expansioncovers the separation of Tanjung Emas port area into two divisions that are an Independent Cargo Terminal and The Harbor Management.Independent Cargo Terminal is under the management of the General Manager of Semarang Cargo Terminal, while The Harbor Managementis under the General Manager of Tanjung Emas Harbor. 


\section{Jurnal Manajemen Teori dan Terapan Tahun 10. No. 2, Agustus 2017}

TPKS is established based on Director's Decree of PT. Pelabuhan Indonesia III (persero) No: KEP.46/PP.1.08/P.III-2001 on June,29th 2001 about the establishment of Semarang Cargo Terminal, which is an independent branch of Tanjung Emas Port in Semarang. Therefore, all matter that is related to cargos handling are completely conducted by Semarang Cargo Terminal management.

TPKS has an important role for the goods' flow (in and out) to the Indonesia's territory, especially Central Java and Jogjakarta. Since the ASEAN Economic Community (AEC) occurs in 2016, the export and import intensity is increasing. The increase in intensity per year is caused by export-import procedures that are getting easier and cheaper. AFTA applied with the decrease in tariff. Moreover, business climate improvement and an increase in trade intensity between ASEAN members also affect export-import intensity. This fact is presented in table 1 that illustrates an increase in the export-import container's quantity in TPKS:

Table 1

Table on the Quantity of Export and Import Cargo in TPKS Semarang during 2013-2015

\begin{tabular}{|l|c|c|c|c|c|c|}
\hline \multirow{2}{*}{$\begin{array}{c}\text { Year } \\
\text { Month }\end{array}$} & \multicolumn{2}{|c|}{$\mathbf{2 0 1 3}$} & \multicolumn{2}{c|}{$\mathbf{2 0 1 4}$} & \multicolumn{2}{c|}{2015} \\
\cline { 2 - 7 } Export & Import & Export & Import & Export & Import \\
\hline January & 13.367 & 11.646 & 13.465 & 13.508 & 16.059 & 15.876 \\
\hline February & 12.038 & 10.703 & 13.706 & 12.484 & 14.973 & 13.995 \\
\hline March & 13.199 & 10.428 & 16.588 & 12.985 & 16.626 & 13.863 \\
\hline April & 12.275 & 11.243 & 15.323 & 14.728 & 15.619 & 15.987 \\
\hline May & 14.646 & 14.306 & 16.199 & 15.572 & 16.812 & 16.804 \\
\hline June & 13.793 & 12.388 & 16.152 & 13.521 & 16.036 & 16.295 \\
\hline July & 13.536 & 13.993 & 15.180 & 12.458 & 12.709 & 8.663 \\
\hline August & 10.175 & 8.565 & 12.450 & 13.179 & 15.309 & 15.783 \\
\hline September & 13.939 & 13.317 & 15.049 & 14.264 & 14.323 & 13.973 \\
\hline October & 14.880 & 12.448 & 14.630 & 13.638 & 14.697 & 15.395 \\
\hline November & 13.778 & 12.005 & 15.107 & 13.752 & 14.986 & 14.468 \\
\hline December & 13.618 & 12.618 & 13.906 & 13.892 & 14.757 & 16.646 \\
\hline TOTAL & $\mathbf{1 5 9 . 2 4 4}$ & $\mathbf{1 4 3 . 6 6 0}$ & $\mathbf{1 7 7 . 7 5 5}$ & $\mathbf{1 6 3 . 9 8 1}$ & $\mathbf{1 8 2 . 9 0 6}$ & $\mathbf{1 7 7 . 7 4 8}$ \\
\hline
\end{tabular}

Source:TPKS Semarang, 2016

The implementation of AEC, bring many convenience to its members. The conveniences are in term of reduction and abolition in tariff. This condition has contributed to the increase in international trade either in and out of Indonesia. The increase in international trade also covers the increase in export-import for each year; it can be seen in the following diagram. 


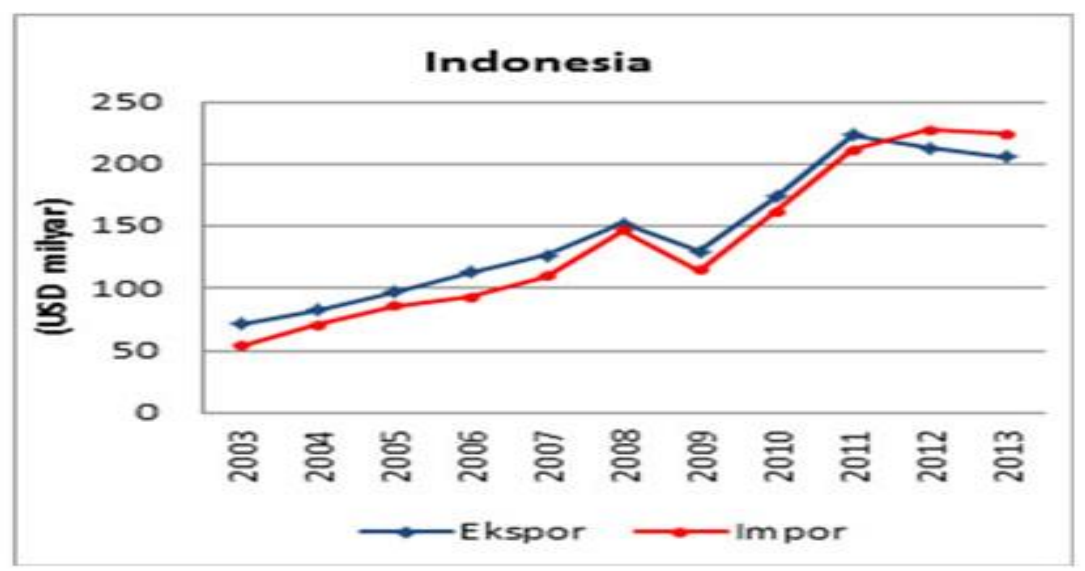

Figure 1. Indonesia Export - Import on ASEAN

Based on Figure 1 there is a significant increase in Indonesia's export- import during 2003 to 2008. In 2009 there is a slight decrease from the previous year's quantity. This decrease is mainly caused by the global economic crisis that occurs in 2008.The decrease is in the price commodity and trade volume in international market affects Indonesia's export value. The economic crisis also increase import intensity to Indonesia during 2008, thus creating a high inflation.

In the 2010-2011, Indonesia's export-import is recovering and increasing significantly. However, in 2012- 2013 the export value decrease again with its import value is higher than its export. Such condition is caused by the decrease in commodity price in the global market. Because of its import value that is higher that its export Indonesia has a deficit trade balance in 2012- 2013.

With a high intensity in import containerwill need an improvement in the harbor system. Otherwise there will be stacking container in the harbor area. The stacking duration will increase the dwelling time. Dwelling time refers to a common measurement to assess the efficiency in general transportation, with a short dwelling time as the main objective (Customs clearance Asia, 2015).

According to Direktorat Jenderal Perhubungan Darat (Directorate General of Land Transport) (2013) in Indonesia Business Daily 2016, dwelling time refers to the amount of waiting time taken by each vehicle at the transit area along its route.This is will affect the efficiency of transportation system in overall. Meanwhile, Import Container's Dwelling time refers to the amount of time that is calculated from when a container is 
unloaded from a ship/vessel until it leaves terminal through the main gate (World Bank, 2011)

Dwelling time poses some significant challenges in Indonesia especially in legal aspect such as bribery. Many violations in loading and unloading process at the harbor emerge some mafias who control imported goods price. The soaring rent price the imported goods price will also increase. Moreover, it will also affect a port's competitiveness. In the AEC era, Indonesian ports are required to reduce dwelling time. High dwelling time affects goods flow in a harbor become slower. Therefore, dwelling time reduction is expected to accelerate the loading-unloading process in a harbor in order to reducing logistic cost. High Dwelling time occurred since there are three phases Pre Clearance, Customs Clearance, and Post Clearance.

Pre clearance is a process that started from the arrival of the transport vehicle (ship/vessels) until a cargo is unloaded from the vehicle and placed in a Container Yard (CY) for having the inspection of notification of imported goods (Pemberitahuan Impor Barang - PIB) registration number. Customs clearance covers the completion of customs documents up to the issuance of Goods Release Approval Letter (Surat Persetujuan Pengeluaran Barang - SPPB). While, post clearance covers container hauling out from port and payment to the port opperated (Shantos, 2015).

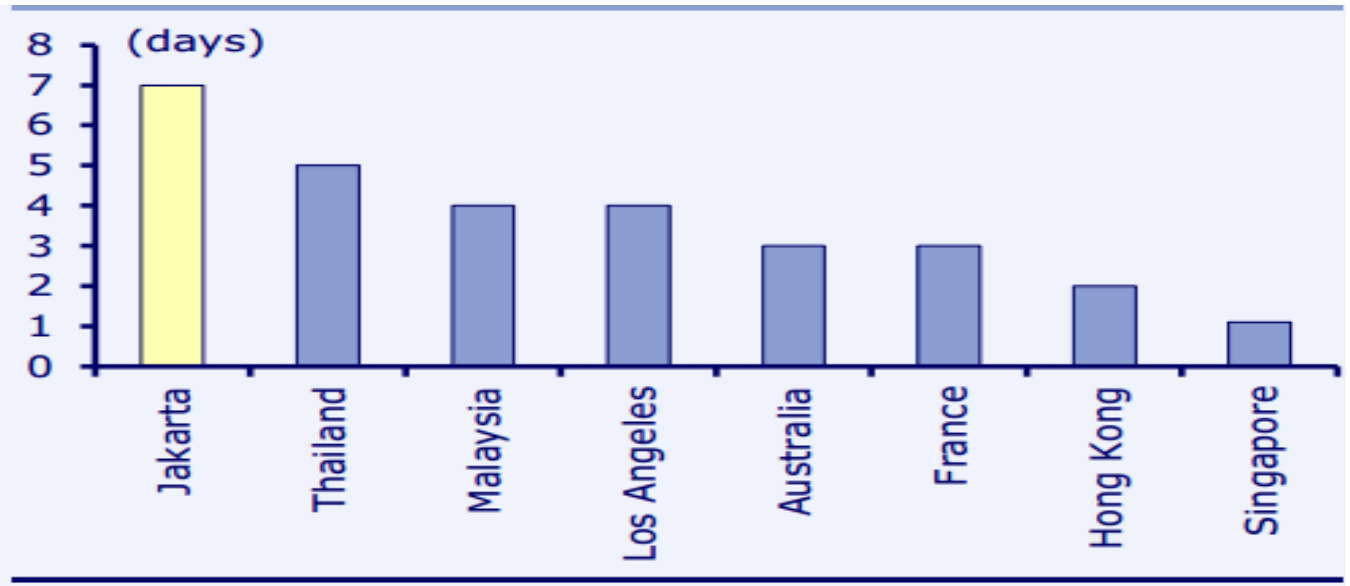

Figure 2. Comparisons on Dwelling Time in Indonesia and Other Countries

Figure 2 shows the comparison of dwelling time in Indonesia and other countries in 2004. In 2004, the average dwelling time in Indonesia is around seven days, while in the other countries is much lower. Dwelling Time in Indonesia is far behind other countries with 


\section{Jurnal Manajemen Teori dan Terapan \\ Tahun 10. No. 2, Agustus 2017}

gaps from Malaysia is three days, Thailand is two days shorter, and Singapore six days shorter.

Thus it can be concluded that dwelling time in Indonesia nowadays still need seven days, while Malaysia has set the maximum dwelling time in four days. This shows that the operational process in Indonesian Port is still inefficient.

An improvement in Port System is needed in order to enable Indonesia to compete with other countries in the AEC. Nowadays, Indonesian government is trying to reduce dwelling time in order to accelerate loading-unloading process on the harbor. The target for dwelling time is around 4.7 days. Thus with such a quick time it can accelerate import container flow, which will increase along with the implementation of the AEC in 2016.

AEC is ASEAN integration in economics which launched on the $9^{\text {th }}$ ASEAN Summit in Bali Concord II. The establishment of such community is initiated by ASEAN countries' head during the 1997 crisis that hit south East Asian countries. AEC is expected to achieve the objective to establish a stable, prosperous, and competitive area with balanced economic growth, reduction in poverty and social-economic gap (Tambunan, 2012). During the Bali Concord II meeting, an AEC blueprint has been prepared as the guidance for the countries' member. There are four pillars in AEC Blueprint as follow:

1. ASEAN as a single market and single production-based is supported by many elements: free flow of goods, skilled labor investment service, and free capital flow.

2. ASEAN as a highly competitive region supported with regulations in costumer protection competition, intellectual property rights, infrastructure development, taxation, and e-commerce.

3. ASEAN as a region with balanced economic growth with the element of small and medium business development; as the ASEAN integration initiator for the CMLV countries (Cambodia, Myanmar, Laos and Vietnam).

4. ASEAN as a region that is fully-integrated with global economy with a coherent approach in term of economic relation outside the region. It is also increasing its role and global production network (Syukriah and Hamdani,2013)

Blue print has been signed as a Roadmap for an ASEAN Community (2009-2015) in the 14th ASEAN summit in HuaHin Thailand. The implementation of AEC in 2016 brings a new configuration in term of distribution and production factor in ASEAN's intra economy.

$A E C$ as one of economic integration formhas the principle and mechanism with free trade (Salvatore, 2014: 311). Theoretically, economic integration refers to a commercial 


\section{Sarjiyanto \\ Khoirul Muslimin}

policy or trading policy with discriminatory manner reducing or eliminating trading constraint between its countries member.

TPKS is one of the biggest port in Java. This port was built in order to expedite goods' transportation processto Indonesia, especially in the Central Java, Jogjakarta, and surrounding area. TPKS is a container handling provider as well as container storage service. The intensity of importing container keeps increasing in this port. Thus, if there is no improvement in TPKS, thestacked container will increase dwelling time.

\section{Research Objective}

Dwelling time refers to the amount of time that is start to calculated when a container is unloaded from a vessel until it leaves terminal through the main gate. High dwelling time will create some losses for many parties if it is not solved. The objective of this research is to give deeper analyze on the preparation and strategy of TPKS in facing dwelling time along the implementation of AEC in 2015.

\section{RESEARCH METHODOLOGY}

This research uses descriptive research design. Research design refers to all process that needed to be done in planning and executing a research (Nazir, 1988: 99). Moleong, (2014: 71) design is guidelines or procedures and techniques in planning a research which aims to develop a useful strategy in developing blueprint or research model. Descriptive research design is a research which arranged in order to provide a systematic overview on scientific formation. As a result of research object or subject which focused on facts obtained during research.

The data used in this research is typically quantitative and qualitative form. Qualitative data is the data that cannot be measured using numeric scale (Kuncoro, 2009: 145). Sugiyono, (2014: 224) mention that qualitative data is data which does not use numeric while the analysis has less clear pattern (more artistic). Thus the result is more about an interpretation of the data obtained.

There are 3 data collection techniques used in this research; 1).Interview, 2).Literature Review, and 3).Observation. Sugiyono (2014: 226) in Esterberg (2002) says an interview is a meeting between two people to exchange information and ideas through a question and answer session. Literature Review is a data collection technique by studying books and article or other information that is related to the problem analyzed. Observation, according to Sugiyono in Nasution (1988) mention observation is the basis of all sciences. Observation is a data collection technique through the process of 
recording of subject (person) behavior, object, or a systematic incident, without any question asked or any communication with the subject and object (Sanusi 2012: 110)

\section{RESULT AND DISCUSSION}

\section{Transportation and logistics process in TPKS with high potential dwelling time}

Based on the Regulation No 26 of 2012 about National Logistic System Development Blueprint, the maximum dwelling time is three (3) days. The higher in dwelling time for an import will generate lower international trade in TPKS.

The calculation of import container dwelling time can be a basis to examine the main cause of high dwelling time in Tanjung Emas Port. The calculation of dwelling time is conducted by considering several processes as the main contributor in high dwelling time in TPKS. Then, we can identify whether dwelling time violate the minimum service standard, thus researcher determine the formula to analyze Import Container Dwelling Tipe as follow:

$$
\mathrm{DT}=\mathrm{TP}+\mathrm{TCC}+\mathrm{TPC}
$$

Notes:

$$
\begin{array}{ll}
\text { DT } & =\text { Dwelling time Import } \\
\text { TP } & =\text { Pre Clearance duration } \\
\text { TCC } & =\text { Customs Clearance duration } \\
\text { TPC } & =\text { Post Clearance duration }
\end{array}
$$

Recently, the dwelling time in TPKS reach 5.6 days. The comparison of the dwelling time from January 2014 to March 2015 is presented in Figure 3 In 2014 dwelling time in TPKS slight decreases from January to March with the average dwelling time around5.922, 5.692, and 5.202days.The average dwelling time increase to 6.316 days in April.

In following year there is a similar decrease in January to March at with average dwelling time 6.926 days in January, to 6.154 days in February, and 5.455 days in March. Meanwhile, in April 2015 there is insignificant increase to 5.79 days. 



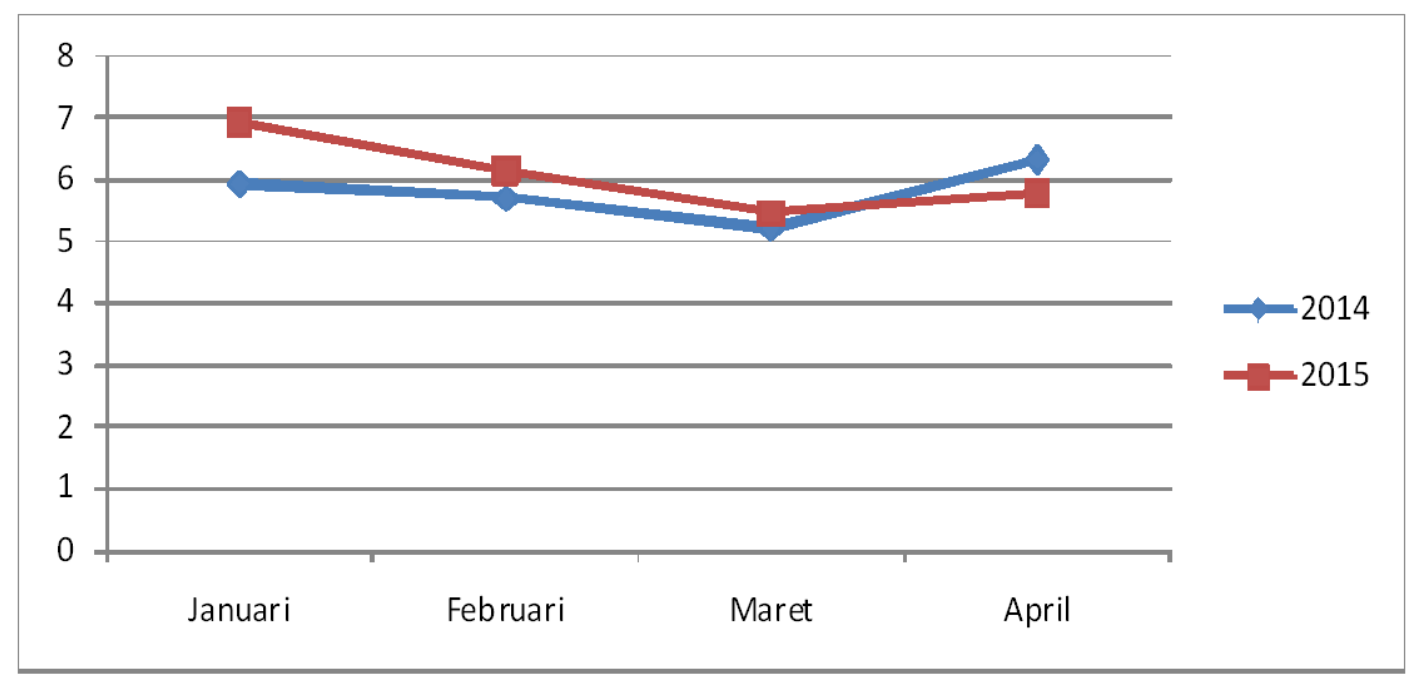

Figure 3 Comparison of Dwelling Time in January-March 2014-2015

Source: Data of TPKS Semarang 2016 (processed)

TPKS that managed under PT IPC (Indonesia Port Company) III is capable to provide loading and unloading service for export and import activities with average dwelling time around 5.6 days. This matter shows a significant effort taken by TPKS to improve its service quality. Based on World Bank survey (2014) the average dwelling time in Indonesian port is around7-8 hours. Dwelling time in TPKS for the last two years is presented in Figure 4

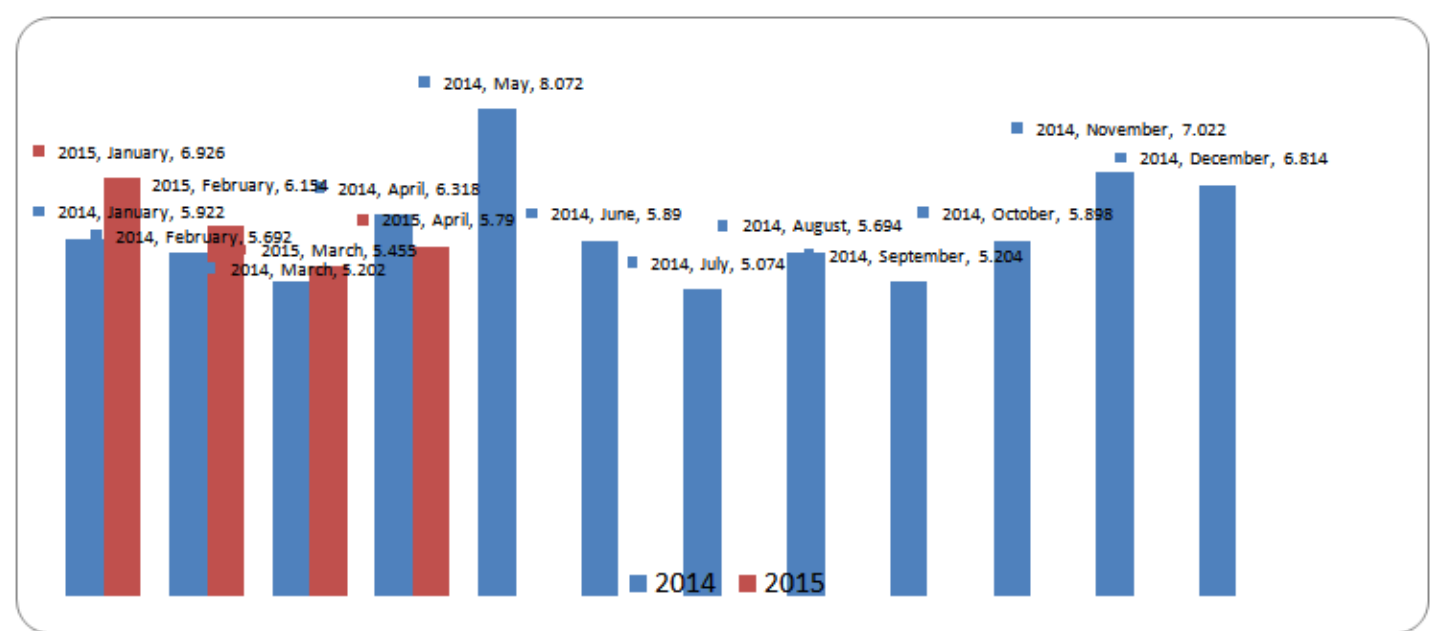

Figure 4. Average Dwelling Time in TPKS for the Last 2 Years Source: TPKS Data 2016

Figure 4 shows the average of dwelling time that keeps fluctuated, but indicates an improvement in overall. TPKS continue to improve its performance to reduced significantly dwelling time target at 3.4 days. 


\section{Jurnal Manajemen Teori dan Terapan \\ Tahun 10. No. 2, Agustus 2017}

Container handling processes in TPKS, pose many potential to increase dwelling time. However, there are three stages that have the most probability to increase the dwelling time namely: Pre Clearance, Customs Clearance, and Post Clearance.

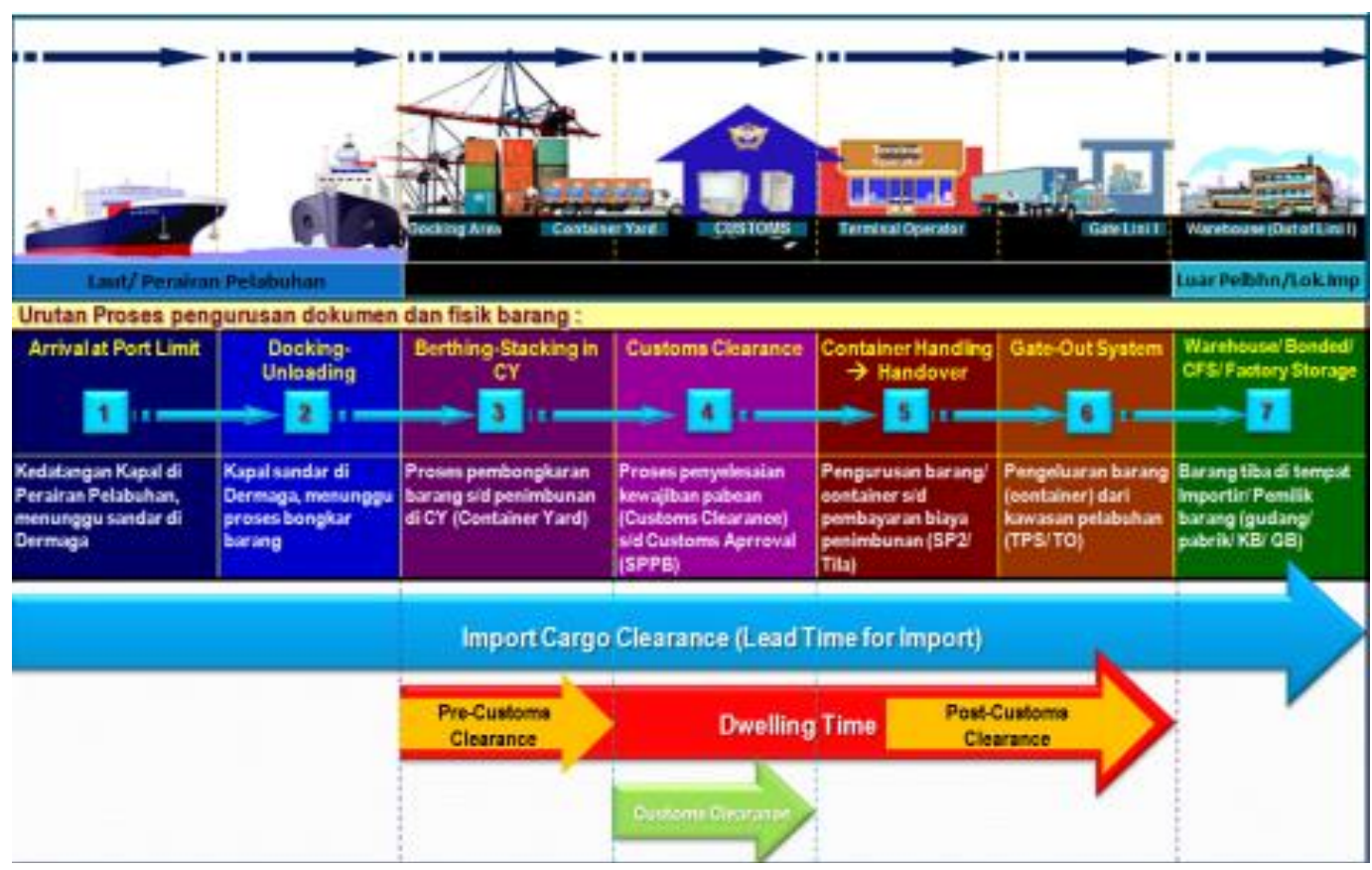

Figure 5 Dwelling Time Process in Port Transportation in Indonesian Port Source: Ministry of Finance Republic Indonesia (2015)

Based on the Figure 5, it can be seen that imported goods handling is identical with three processes that can increase dwelling time. These processes refer to a cycle started from the arrival of the vessels until a cargo is unloaded and placed in a temporary storage (CY) for the inspection of notification of imports of goods (PIB) registration number. During the pre-clearance stage, TPKS has an important role to unload the container from vessel and transfer it to the temporary storage. This process needs 2.6 days.

Customs clearance covers the completion of customs documents up to the issuance of Goods Release Approval Letter (SPPB).This stage is involving Indonesian Customs for physical checking. In this stage tends to take more time, especially for the container on the red lane since it is involving the must physical checking. This stage needs 1.6 days in process.

While post clearance covers container hauling out from port and realize payment to the port operator. This stage is involving many parties such as freight forwarders (PPJK), trucking companies, and importer, with duration approximately 1.4 days. In this process, 
importer or goods owner usually contributes to the high dwelling time. It is mainly because the tariff set to store the container is low, thus the owner usually let their cargo stay longer at the storage. The detail about this process is presented in Table 1.2 
Table 1.3

Strategy in Reducing Dwelling time in TPKS

\begin{tabular}{|c|c|c|c|c|}
\hline & Pre clearance & Customs clearance & Post Clearance & $\begin{array}{c}\text { Target } \\
\text { \& Realization }\end{array}$ \\
\hline $\begin{array}{l}\text { Activities } \\
\text { Conducted }\end{array}$ & $\begin{array}{l}\text { Completion of import } \\
\text { permit and unloading } \\
\text { process up to goods } \\
\text { storing in the temporary } \\
\text { storage }\end{array}$ & $\begin{array}{l}\text { Completion of customs obligations } \\
\text { up to the issuance of Goods } \\
\text { Release Approval Letter (SPPB); all } \\
\text { process are involving Indonesian } \\
\text { customs }\end{array}$ & $\begin{array}{l}\text { Divided into } 2 \text { stages: the first one relate with } \\
\text { Container Handling Handover which is related } \\
\text { with container handling up to payment and } \\
\text { followed by Gate Out System which is } \\
\text { container release from the port area }\end{array}$ & \\
\hline Duration & 2.6 & 1.6 & 1.4 & $\begin{array}{c}\text { Realization } \\
5.6 \text { days }\end{array}$ \\
\hline $\begin{array}{l}\text { High } \\
\text { Dwelling time } \\
\text { caused by }\end{array}$ & 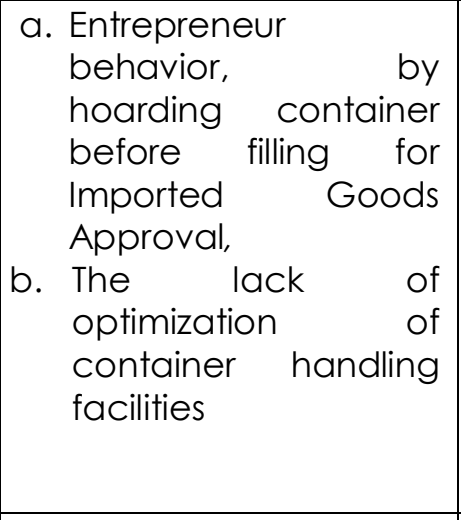 & $\begin{array}{l}\text { a. High number of container in the } \\
\text { red and yellow lane } \\
\text { b. The lack of Customs officer } \\
\text { related to physical checking } \\
\text { (red lane) and document } \\
\text { checking (yellow lane) } \\
\text { c. Integrated Physical Checking } \\
\text { Sites (Tempat Pemeriksaan Fisik } \\
\text { Terpadu - TPFT) has not been } \\
\text { operated for } 24 \text { hours, thus the } \\
\text { container in red and yellow line } \\
\text { to piled-up }\end{array}$ & $\begin{array}{l}\text { a. Entrepreneur behavior by delaying } \\
\text { container pick-up eve though the } \\
\text { permission from DJBC is already issued. } \\
\text { b. Long DO time from the shipping } \\
\text { companies }\end{array}$ & $\begin{array}{c}\text { Target } 3 \\
\text { days }\end{array}$ \\
\hline $\begin{array}{l}\text { Implemented } \\
\text { Strategy to } \\
\text { Overcome } \\
\text { Dwelling } \\
\text { Time Problem }\end{array}$ & $\begin{array}{l}\text { Coordination with } \\
\text { importers, related to the } \\
\text { acceleration of PIB } \\
\text { issuance and performing } \\
\text { optimizations on the } \\
\text { facilities for containers } \\
\text { handling }\end{array}$ & $\begin{array}{l}\text { Encourage to accelerate the } \\
\text { completion of related document } \\
\text { and acceleration in physical } \\
\text { checking, by applying } 24 \text { hours } \\
\text { TPFT }\end{array}$ & $\begin{array}{l}\text { Encourage entrepreneurs to pick the } \\
\text { containers as soon as all of the requirements } \\
\text { are completed. }\end{array}$ & \\
\hline
\end{tabular}




\section{TPKS action to reduce dwelling time in facing AEC by the year 2016}

TPKS as one of business unit in PT. IPC III (Persero) or known as PELINDOIII continue to show increase on its loading and unloading activities. During 2014 there are 341,736 TEUs (Twenty feet Equivalent Units) container been processed. This amount is keep increasing up to360, 654 TEUs in 2015.TPKS optimized its performance through improvements and additions of infrastructure along with the implementation of AEC in 2016. This attempt also aims to reduce dwelling time in the TPKS area from 5.6 days to 3 days process. The efforts made are as follow:

\section{a. Service Improvement Strategy}

TPK Supply an online strategy in job order management. This strategy is an effort to improve the manual system which takes more time. TPKS conduct some improvement to enhance the time efficiency by implementing 24 hours online system for the job order filling. With such strategy, job order management becomes more efficient since with the online system export and import service can be accessed for 24 hours from any places. Compared to the old system those only allow the service to be accessed during working time.

b. Service Facilities Optimization

The management of TPKS has been improving and adding more loading-unloading facilities, such as: enlarging its Container Yard (CY) with the land area of 5.3 hectares. Additional 105 meters piers thus it will have 600 meters pier in total (previously 495 meters). This additional makes TPKS pier can accommodate three vessels at one time.

TPKS procuring 2 units Container Crane (CC) and 11 units of automated new Rubber Tired Gantry (ARTG). Thus in total there will be $7 \mathrm{CC}$ in operation. Moreover, apart from CC and ARTG addition, TPKS planned to add more Reach Stacker and Combined Terminal Tractor. TPKS also prepare an Integrated Physical Checking Sites (Tempat Pemeriksaan Fisik Terpadu - TPFT) for imported goods. Time efficiency is the main objective of this site. Previously, the physical checking needs 4-5 days. But with TPFT, this time can be reduced to only 2-3 days.

TPFT will operate for 24 hours a day and 7 days in a week for no maximum quantity to be checked in a day. All goods that have been passed the check can be pickedup by its owner to be stored in their own storage. However, if there is any discrepancy, the object will be processed in accordance with the predefined procedures. Goods release from TPFT will be quicker so that it can reduce container stacking.

c. Human Resource Improvement 


\section{Jurnal Manajemen Teori dan Terapan \\ Tahun 10. No. 2, Agustus 2017}

If the improvement and preparation is only conducted on the facilities and system, to be sure it will not work properly. Therefore, TPKS has conducting several training for its staff in order to face AEC implementation. Transportation management skill for logistics of international cargo handling certification is the main objective for the training.

d. The parties related to high dwelling time High dwelling time in TPKS not only caused by TPKS management, but it is also related to many other parties. There are four parties who related with a high dwelling time in TPKS as follow:

1. TPKS as container handling service provider.

2. Directorate General of Indonesian Customs as the agency in charge to issue export-import license.

3. Importer as the main actor in import activities.

4. Freight forwarding (PPJK) as customs Clearance Company, as the authorized party to handle all important matters in import activities.

\section{CONCLUSION AND DISCUSSION}

\section{Conclusion}

Based on the analysis of dwelling time in TPKS in the AEC era, it can be concluded that.

1. The highest probability to increase dwelling time in TPKS occurring on pre clearance, customs clearance, and post clearance process. Those activities need 5.6 days while the government target is 4.7 days.

2. TPKS has several plans and preparation related to the implementation of AEC in 2015. The plans and preparation cover online system for the job order, facilities improvement, and human resource development. All of these activities aim to support the loading and unloading activities on the harbor as well as to reduce dwelling time.

3. High dwelling time in TPKS is not only caused by TPKS. There are several parties who related with this problem such as TPKS staff, Indonesian Customs, importer and PPJK or freight forwarder.

\section{Discussion}

1. There should be a simplification in the pre clearance, customs clearance, and post clearance activities. The simplification will reduce dwelling time as target has been fixed by the authority. 


\section{Sarjiyanto}

\section{Khoirul Muslimin}

2. Undertake a performance optimization in accordance with the preparation in entering the AEC era in 2015. This aims to meet the target set by government in dwelling time that is 3.7 days, or even shorter than the target.

3. A good mutuality Coordination between related parties, who involved in dwelling time actually needed. This is to realize efficiently process and reducing dwelling time.

\section{REFERENCE}

Chairi, B. (2015). Menjadi Juara di Era MEA 2015. Jakarta.

Cukai, K. d. (2016, Maret 5). Indeks Kepabeanan. diakses Maret 5. 2016, dari Direktorat Jendral Bea DanCukai:http://www.beacukai.go.id/arsip/pab/impor.html

Direktorat Jenderal Perhubungan Darat. (2011). kasus ekonomi apa itu dwelling time.

G.T. Suroso. (2015). Masyarakat Ekonomi Asean (MEA) dan Perekonomian Indonesia. Diambil kembali dari bppk kemenkeu:http://www.bppk.kemenkeu.go.id/publikasi/artikel/150artikel-keuangan-umum/20545-masyarakat-ekonomi-asean-mea-dan-perekonomianindonesia

Kuncoro, M. (2009 : 145). Metode Riset untuk Bisnis \& Ekonomi edisi 3. jogjakarta : Erlangga.

Mar, C. R. (2005). Shipping Pengangkutan Ekspor Impor melalui lau. Jakarta: PPM.

Moh.Nazir, P. (1988: 99). Metode Penelitian .Jakarta timur: Ghalia Indonesia.

MS, Amir. (2000) ). Perdagangan Luar Negri .

MS, Amir. (2004 : 1). PPM. Jakarta

MS, Amir. (2004 : 139). PPM. Jakarta

Nurmawati, B. (2015) Indonesia Menuju Asean Economic Community (AEC) Jurnal IUS Facti, 2015: 3.

Rompas, Rizald Max dkk. Pengantar Ilmu Kelautan. Jakarta: Sekretaris Dewan Kelautan Indonesia.

Salvato, Dominic. (2014). Ekonomi International. Jakarta: Salemba Empat.

Sanusi, A. (2012). Metode penelitian bisnis. Jakarta: Salemba Empat.

Shantoso, K. (2015). Dwelling Time Menkeu tuding biang kerok di Preclereance. Dipetik Maret 30, 2016, dari Finansial Business: http://finansial.bisnis.com/read/20150625/9/444945/dwelling-time-menkeu-tudingbiang-kerok-di-pre-clearance

Sudijono dan Sarjianto (2015). Transportasi Ekspor Impor dan Tatalaksana Kepabeanan. Surakarta.

Sugiyono, P. (2014). Metode Kuantitatif Kualitatif dan R \& D. Jakarta: Alfabeta.

Tangjung, M. (2011). Praktik dan Prosedur Ekspor Impor. Salemba Empat.

TPKS. (2014). Sistem dan Prosedur. Semarang Penagangan Kontainer di TPKS Semarang.

ASEAN (2002), ASEAN Maritime Transport Development Study, ASEAN, Jakarta. 
Coordinating Ministry for Economic Affairs, Republic of Indonesia 2011, Masterplan for Acceleration andExpansion of Indonesia Economic Development 2011-2025 Ministry of National Development Planning/ National Development Planning Agency, Jakarta.

Indonesia Associates (2010), List of Indonesia Coal Ports 2009, viewed on website of IndonesiaAssociates, www.indonesiaassocaite.com.

Meyrick and Associates (2005), Promoting Efficient and Competitive Intra-ASEAN Shipping Services: Country Paper, Indonesia, Report of REPSF Project No. 04/001, ASEAN, Jakarta.

World Bank (2005), Rail Efficiency Project: Implementation Completion Report, Transport Sector Unit,East Asia and the Pacific Unit, World Bank, New York.

World Bank (2006), Port Reform Toolkit: Effective Support for Policy Makers and Practitioners, 2ndEdition, World Bank Public-Private Infrastructure Advisory Facility, Washington.

World Bank (2011), Logistics Performance Indicator 2010: Indonesia, World Bank, Washington 
Sarjiyanto

Khoirul Muslimin 